\title{
Crystallization and Structural Characterization of Dimeric and Trimeric Forms of (Neocuproine) $\mathrm{CdFe}(\mathrm{CO})_{4}$
}

\author{
Torsten Kolb, Atta M. Arif, and Richard D. Ernst \\ Department of Chemistry, University of Utah, 315 South 1400 East, Room 2020, Salt Lake City, UT 84112-0850, USA \\ Correspondence should be addressed to Richard D. Ernst; ernst@chem.utah.edu
}

Received 24 October 2013; Accepted 22 January 2014; Published 11 March 2014

Academic Editor: Dong Qiu

Copyright (C) 2014 Torsten Kolb et al. This is an open access article distributed under the Creative Commons Attribution License, which permits unrestricted use, distribution, and reproduction in any medium, provided the original work is properly cited.

\begin{abstract}
The previously reported (neocuproine) $\mathrm{CdFe}(\mathrm{CO})_{4}$ has been found to crystallize as either a dimer or a trimer depending on the procedure used. These species exist as nearly planar four- and six-membered rings composed of alternating cadmium and iron atoms. The trimeric form is reasonably similar to its $2,2^{\prime}$-bipyridyl analogue, while the dimeric form had not been observed previously for a $\mathrm{L}_{x} \mathrm{CdFe}(\mathrm{CO})_{4}$ complex. The space group for the dimeric isomer is $C 2 / c$, with $a=20.7044(3), b=12.2169(2)$, $c=13.7837(2) \AA$, and $\beta=98.1226(11)^{\circ}$, while for the trimeric isomer the space group is $P \overline{1}$, with $a=14.5056(1), b=15.4331(1)$, $c=17.3372(2) \AA, \alpha=110.0059(3)^{\circ}, \beta=104.2580(4)^{\circ}$, and $\gamma=95.2796(5)^{\circ}$.
\end{abstract}

\section{Introduction}

The complex $\mathrm{CdFe}(\mathrm{CO})_{4}$ (1) was first reported in 1933 and due to its insolubility was proposed to be a polymeric species $[1,2]$. A subsequent study revealed it to be tetrameric, composed of a square, eight-membered ring having alternating cadmium and iron atoms, bearing nearly linear and cisdisubstituted octahedral coordination geometries, respectively [3]. In contrast to its mercury analogue [4], 1 has been found to readily incorporate ligands into its coordination sphere, generating a variety of $\left[\mathrm{L}_{x} \mathrm{CdFe}(\mathrm{CO})_{4}\right]_{n}$ complexes (e.g., $\mathrm{L}=\mathrm{NH}_{3}$ or py, $x=2 ; \mathrm{L}_{2}=2,2^{\prime}$-bipyridine or 1,10 phenanthroline [2]). As can be seen, these most commonly involve two coordination sites on cadmium being occupied by amines, though THF coordination is also possible, and at least one $[\mathrm{LCdFe}(\mathrm{CO})]_{n}$ species $(\mathrm{L}=4$-phenylpyridine $)$ [5] and at least one monomeric $\mathrm{L}_{3} \mathrm{CdFe}(\mathrm{CO})_{4}$ complex, in which $\mathrm{L}_{3}$ represents a combination of one pyridine and one bidentate neocuproine (2,9-dimethylphenanthroline) ligand [6], are known. The isolation of the monomeric species appears to have been promoted by the use of pyridine as the solvent for crystallization. Further, the use of the chelating tren ligand appears, from spectroscopic data, also to have led to a monomeric complex [5]. In comparison, analogous complexes with the harder zinc ion are typically found as monomeric $\mathrm{L}_{3} \mathrm{ZnFe}(\mathrm{CO})_{4}$ species $\left(\mathrm{L}=\mathrm{NH}_{3}\right.$ or pyridine [2] or $\mathrm{L}_{3}=\left(\mathrm{NH}_{3}\right)\left(2,2^{\prime}\right.$-bpy) $\left.[5,6]\right)$. An unusual dianionic species, $\left\{\left[\mathrm{CdFe}(\mathrm{CO})_{4}\right]_{6} \mathrm{Cl}_{2}(\mathrm{DME})_{2}\right\}^{2-}$, has also been reported [7] and found to contain a twelve-membered ring, thus far the largest known. The use of larger iron carbonyl anions, such as $\mathrm{Fe}_{2}(\mathrm{CO})_{8}{ }^{2-}$ or $\mathrm{Fe}_{3}(\mathrm{CO})_{11}{ }^{2-}$, has thus far not led to oligomers but instead to species possessing $\mathrm{CdFe}_{2}$ rings $[8,9]$.

To date, the only $\left[\mathrm{L}_{2} \mathrm{CdFe}(\mathrm{CO})_{4}\right]_{n}$ species to have been crystallographically characterized have been the $\mathrm{L}=$ THF or pyridine (py) or $\mathrm{L}_{2}=2,2^{\prime}$-bipyridine species [10], which have all been found to exist as trimeric complexes. Notably, the $\left(2,2^{\prime}\right.$-bipyridine)zinc analogue (2) has been found to exist as a dimer [11]. The general structures of these arrangements may be seen in Figure 1. In order to attempt to gain a better understanding of the factors that control the extent of oligomerization in these complexes, we have pursued the characterization of additional complexes which incorporate more highly modified ligands, such as neocuproine. While $[$ (neocuproine $\left.) \mathrm{CdFe}(\mathrm{CO})_{4}\right]_{n}$ has indeed been synthesized [6], its degree of association had not yet been determined, though a structural study of the monomeric (py)(neocuproine) $\mathrm{CdFe}(\mathrm{CO})_{4}$ complex was carried out. We 


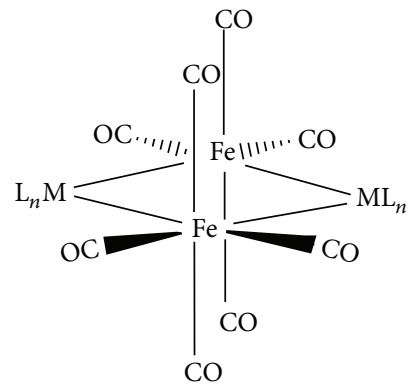

(a)

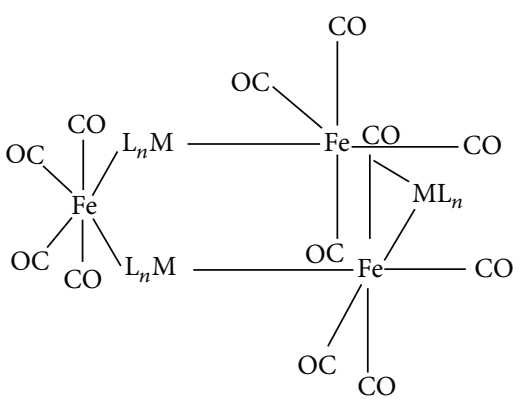

(b)

Figure 1: General structures of $\mathrm{L}_{2} \mathrm{CdFe}(\mathrm{CO})_{4}$ dimers (a) and trimers (b).

now report that the use of neocuproine allows for the isolation of both the dimeric and the trimeric isomers.

\section{Materials and Methods}

All reactions were carried out in a Schlenk apparatus under a nitrogen atmosphere.

Due to the low solubility of the neocuproine complex(es), it appeared that it might be most effective to attempt crystallization of the complex as it was formed. In order to moderate the rate of formation, it seemed advisable to use a reasonably soluble $\left[\mathrm{L}_{2} \mathrm{CdFe}(\mathrm{CO})_{4}\right]_{n}$ complex as starting material, particularly with $\mathrm{L}_{2}$ being a chelating ligand. While ethylenediamine might have seemed suitable, the low solubility of $\left[(\mathrm{en}) \mathrm{CdFe}(\mathrm{CO})_{4}\right]_{n}[2]$, as well as its tetramethyl analogue, led us to utilize tetraethylethylenediamine as the chelate. The teeda complex can be easily prepared by the reaction of stoichiometric teeda with $\left[\left(\mathrm{NH}_{3}\right)_{2} \mathrm{CdFe}(\mathrm{CO})_{4}\right]_{n}$ in THF, after which a concentrated solution crystallizes very nicely on cooling to $-30^{\circ} \mathrm{C}$. From the $\left[(\text { teeda }) \mathrm{CdFe}(\mathrm{CO})_{4}\right]_{n}$ starting material, an apparently lighter and a darker form of crystalline neocuproine complex could be isolated. It was subsequently found that the formation of the paler form could be favored by rapid mixing of the starting materials. As a general example of its isolation, approximately $0.20 \mathrm{~g}$ of $\left[\text { (teeda) } \mathrm{CdFe}(\mathrm{CO})_{4}\right]_{n}$ was dissolved in $20 \mathrm{~mL}$ of THF in a Schlenk flask under nitrogen, and $0.094 \mathrm{~g}$ of neocuproine was added. After shaking the mixture to ensure complete dissolution, the flask was set aside in a still location. Within several hours some well-formed red crystals had deposited. In contrast, formation of the darker isomer was favored through reactions involving slower contact between the two reactants. Thus, a small amount of $\left[(\text { teeda }) \mathrm{CdFe}(\mathrm{CO})_{4}\right]_{n}$ was placed in a Schlenk tube under nitrogen, and a $1-2 \mathrm{~cm}$ long test tube ( $1 \mathrm{~cm}$ or less diameter) with some solid neocuproine in the bottom, covered carefully with liquid THF, was placed therein. THF was then carefully added to the Schlenk tube, attempting to minimize initial dissolution of the cadmium starting material, until a level was reached about $1 \mathrm{~cm}$ above the top of the test tube. Within 2-3 weeks some nice dark red prisms had formed.

Single crystals of each compound were mounted on glass fibers with Paratone oil and transferred to a Nonius Kappa
CCD diffractometer. The dimer and the trimer were found to have monoclinic and triclinic unit cells (Table 1), and their space groups were determined from systematic absences and the successful solutions of the structures. Data collection and processing utilized the programs COLLECT, DENZO-SMN, and SCALEPAC [12]. The structures were solved using heavy atom and direct methods with SIR97 [13] and SHELXL97 [14]. Final refinements were carried out with anisotropic thermal parameters for all nonhydrogen atoms. The nonmethyl hydrogen atoms in the dimer were successfully refined isotropically, while all other hydrogen atoms were given isotropic thermal parameters and were allowed to ride on their attached carbon atoms. Four molecules of THF were also found in the lattice of the trimer, one of which suffered a severe disorder. Scattering factors were taken from the literature $[15,16]$.

Molecular plots were obtained using the ORTEP3 for Windows program [17].

The CCDC depositions 967908 and 967909 contain the full crystallographic information for the dimeric and trimeric structures, respectively. These data can be obtained free of charge via http://www.ccdc.cam.ac.uk/conts/retrieving.html or from the Cambridge Crystallographic Data Centre, 12 Union Road, Cambridge CB2 1EZ, UK; fax: (+44) 1223-336033 or e-mail: deposit@ccdc.cam.ac.uk.

\section{Results and Discussion}

It is first of interest to try to explain how the differing crystallization schemes could favor different isomeric forms of $[$ (neocuproine $\left.) \mathrm{CdFe}(\mathrm{CO})_{4}\right]_{n}(n=2(3)$ or $3(4))$. One possibility is that the difference is driven by the local concentrations of the starting material $\left[(\text { teeda }) \mathrm{CdFe}(\mathrm{CO})_{4}\right]_{n}$ and/or a monomeric (THF)(teeda) $\mathrm{CdFe}(\mathrm{CO})_{4}$ complex. In the case in which both reactants are mixed thoroughly from the start, there will be a higher local concentration of metal complex, so that as two monomers link, but prior to closing to a ring, it will not be long before a third is encountered, leading to the selective formation of the trimer. In the slower mixing process, an incipient but not yet cyclized dimer will not as quickly encounter a third metal complex and thus may ultimately cyclize to the dimer, despite its substantial steric strain (vide infra). 
TABLE 1: Crystal and experimental data.

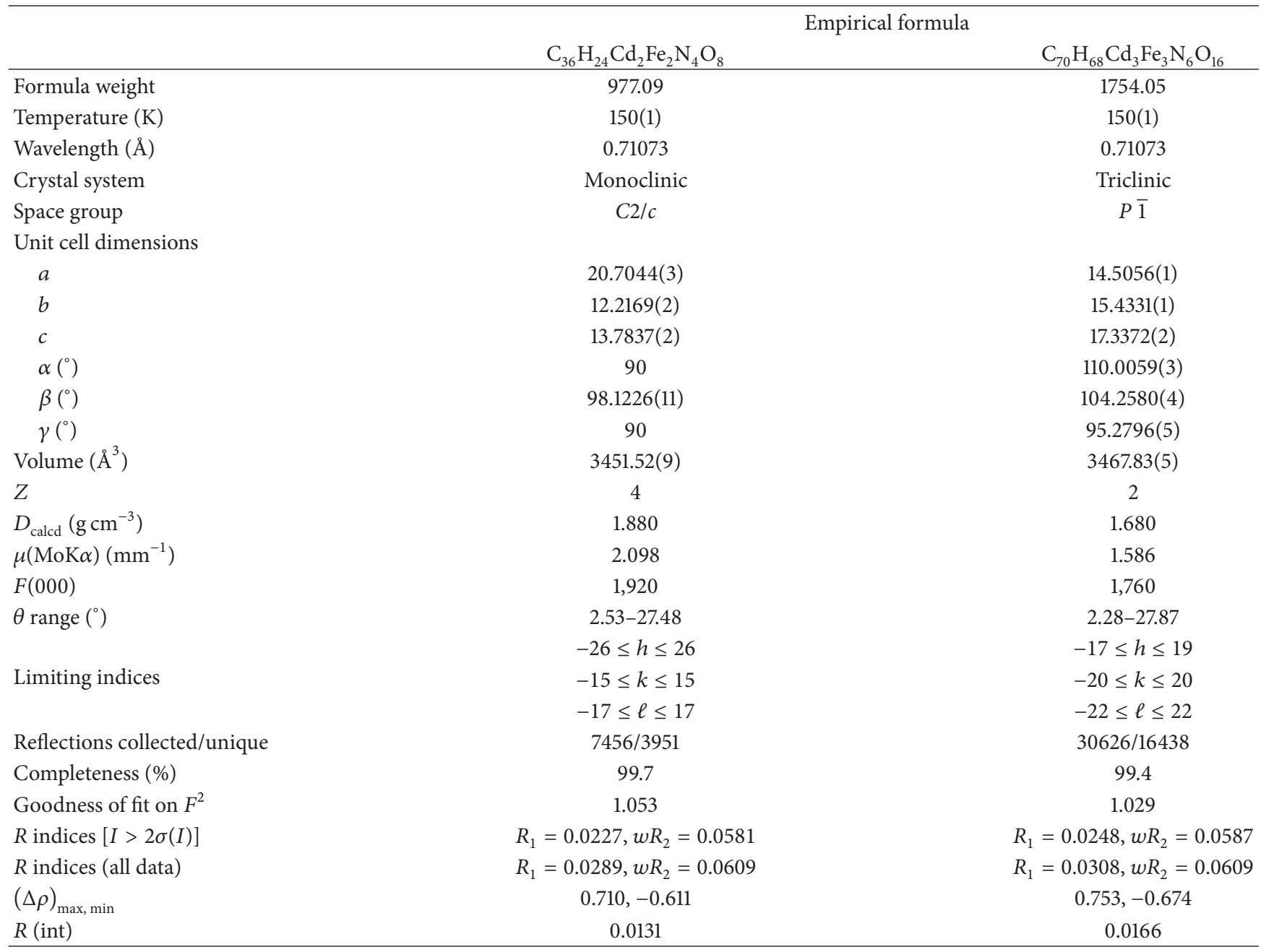

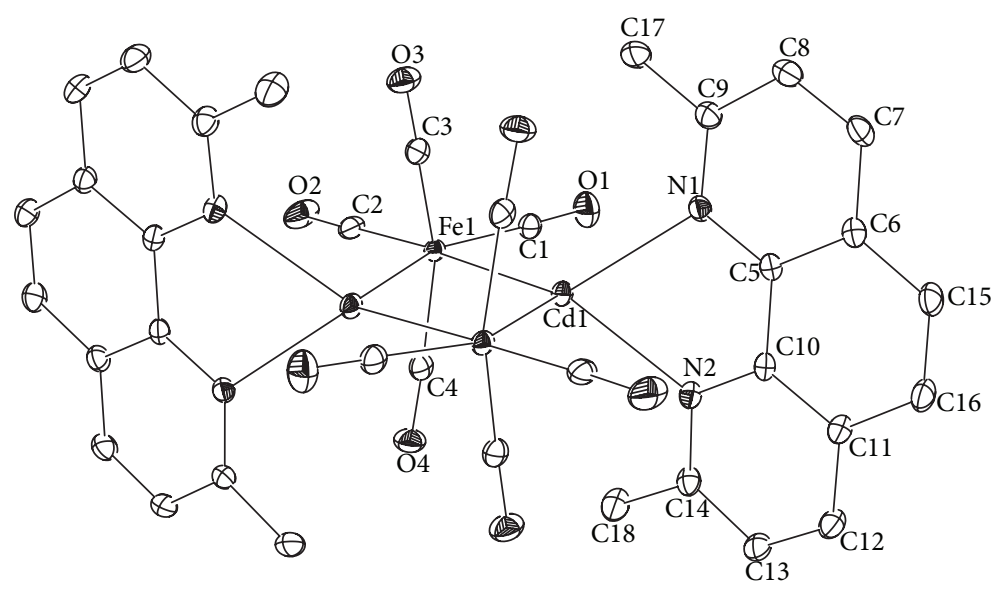

FIGURE 2: The structure of $\left[(\text { neocuproine }) \mathrm{CdFe}(\mathrm{CO})_{4}\right]_{2}$ (30\% probability ellipsoids).

The dimeric isomer 3 displays a structure (Figure 2) which is fairly similar to the related $\left[\left(2,2^{\prime}\right.\right.$-bipyridine $)$ $\left.\mathrm{ZnFe}(\mathrm{CO})_{4}\right]_{2}$, 2. As opposed to complex 2, which is situated on an inversion center and as a result is rigorously planar, 3 has imposed twofold rotational symmetry and is thus not quite planar, with opposing deviations of $0.042 \AA$ for the cadmium and iron centers. One can next notice that the "axial" carbonyl ligands on iron exhibit significant tilts, such that the $\mathrm{C} 3-\mathrm{Fe}-\mathrm{C} 4$ angle is $146.59(10)^{\circ}$, as compared to $150.05(14)^{\circ}$ for 2 (Table 2). This tilt is attributed to 
TABLE 2: Selected bond lengths $(\AA)$ and angles $\left(^{\circ}\right)$ for [(neocuproine) $\left.\mathrm{CdFe}(\mathrm{CO})_{4}\right]_{2}$.

\begin{tabular}{lccc}
\hline \multicolumn{4}{c}{ Bond distances } \\
Cd1-Fe1 & $2.6532(3)$ & Cd1-Fe1' & $2.8125(3)$ \\
Cd1-N1 & $2.3635(17)$ & Cd1-N2 & $2.3621(17)$ \\
Fe1-C1 & $1.780(2)$ & C1-O1 & $1.154(3)$ \\
Fe1-C2 & $1.770(2)$ & C2-O2 & $1.146(3)$ \\
Fe1-C3 & $1.775(2)$ & C3-O3 & $1.163(3)$ \\
Fe1-C4 & $1.772(2)$ & C4-O4 & $1.165(3)$ \\
\hline \multicolumn{5}{c}{ Bond angles } \\
Fe1-Cd1-Fe1 & $111.243(9)$ & Cd1-Fe2-Cd1' & $68.642(9)$ \\
C1-Fe1-C2 & $101.75(11)$ & Fe1-C1-O1 & $176.3(2)$ \\
C1-Fe1-C3 & $103.96(10)$ & Fel-C2-O2 & $178.2(2)$ \\
C1-Fe1-C4 & $105.24(10)$ & Fel-C3-O3 & $173.5(2)$ \\
C2-Fe1-C3 & $95.81(9)$ & Fel-C4-O4 & $172.4(2)$ \\
C2-Fe1-C4 & $93.83(9)$ & Cd1-Fe1-C1 & $81.01(7)$ \\
C3-Fe1-C4 & $146.59(10)$ & Cd1'-Fe1-C2 & $108.65(8)$ \\
N1-Cd1-N2 & $71.36(6)$ & & \\
\hline
\end{tabular}

a contribution from an ionic resonance hybrid involving coordinated $\mathrm{Cd}^{2+}$ and the $\mathrm{Fe}(\mathrm{CO})_{4}{ }^{2-}$ ions. This angle is very close to being midway between the octahedral and facebicapped tetrahedral extremes, as is also the $\mathrm{C} 1-\mathrm{Fe}-\mathrm{C} 2$ angle of $101.75(11)^{\circ}\left(103.25(16)^{\circ}\right.$ for 2$)$. These tilts lead to a close approach between the axial carbonyls on one iron center and those of the other, which then results in a twist of the tetrahedra toward opposite cadmium centers. Even so, the $\mathrm{O} 3-\mathrm{O}^{\prime}{ }^{\prime}$ and $\mathrm{O} 4-\mathrm{O} 4^{\prime}$ contacts are still rather close at 3.327 and $3.788 \AA$, with shorter $\mathrm{O} 3-\mathrm{Cl}^{\prime}, \mathrm{O} 4-\mathrm{C} 18^{\prime}$, and $\mathrm{Cd}-\mathrm{Cd}^{\prime}$ contacts of $3.190,3.148$, and $3.085 \AA$. One way of gauging this distortion is to compare the $\mathrm{Cd} 1-\mathrm{Fel}-\mathrm{Cl}$ and $\mathrm{Cd1}{ }^{\prime}-\mathrm{Fel}-\mathrm{C} 2$ angles of $81.01(7)^{\circ}$ and $108.65(8)^{\circ}$, reflecting by this measure an approximate twist of $14^{\circ}\left(84.40(14)^{\circ}\right.$ and $106.42(9)^{\circ}$ for 2). The twist also causes each cadmium to adopt something closer to an edge- rather than face-capping position on one of the adjacent iron centers. In fact, while face-capped tetrahedral resonance forms can contribute substantially to the overall makeup of these compounds, in this case the structure actually appears to resemble an equatorial edgecapped trigonal bipyramidal arrangement (Figure 3).

The respective Cd1-Fel-Cd1' and Fe1-Cd1-Fel' angles of $68.642(9)^{\circ}$ and $111.243(9)^{\circ}$ also compare well with the values of $66.02(2)^{\circ}$ and $113.98(2)^{\circ}$ for 2 . However, other parameters differ markedly. While a modest difference in $\mathrm{Zn}-\mathrm{Fe}$ bond distances was observed in 2 (2.585(1) and 2.532(1) $\AA$ ), the Cd1-Fel and Cd1-Fel' bond lengths were observed to be 2.6532(3) and 2.8125(3) A. Additionally, there is a greater nonlinearity of the axial carbonyl ligands, with the Fe1-C3-O3 and Fe1-C4-O4 angles being 173.5(2) ${ }^{\circ}$ and $172.4(2)^{\circ}$ (versus $176.3(3)^{\circ}$ and $173.9(3)^{\circ}$ in 2 ). These enhanced distortions can most likely be attributed to contacts between the axial carbonyl oxygen atoms and methyl groups of the neocuproine ligand.

Overall, the trimeric isomer (Figure 4) exhibits far less distortion compared to the dimer. This can first be seen
TABLE 3: Selected bond lengths $(\AA)$ and angles $\left(^{\circ}\right)$ for [(neocuproine) $\left.\mathrm{CdFe}(\mathrm{CO})_{4}\right]_{3}$.

\begin{tabular}{|c|c|c|c|}
\hline \multicolumn{4}{|c|}{ Bond distances } \\
\hline $\mathrm{Cd} 1-\mathrm{Fe} 2$ & $2.7258(3)$ & $\mathrm{Cd} 1-\mathrm{Fe} 3$ & $2.7307(3)$ \\
\hline $\mathrm{Cd} 2-\mathrm{Fe} 1$ & $2.6969(3)$ & $\mathrm{Cd} 2-\mathrm{Fe} 3$ & $2.7287(3)$ \\
\hline $\mathrm{Cd} 3-\mathrm{Fe} 1$ & $2.7307(3)$ & $\mathrm{Cd} 3-\mathrm{Fe} 2$ & $2.7251(3)$ \\
\hline Fel-C1 & $1.777(2)$ & C1-O1 & $1.149(3)$ \\
\hline Fe1-C2 & $1.780(2)$ & $\mathrm{C} 2-\mathrm{O} 2$ & $1.152(3)$ \\
\hline Fel-C3 & $1.774(2)$ & $\mathrm{C} 3-\mathrm{O} 3$ & $1.162(3)$ \\
\hline Fe1-C4 & $1.777(2)$ & $\mathrm{C} 4-\mathrm{O} 4$ & $1.159(3)$ \\
\hline $\mathrm{Fe} 2-\mathrm{C} 5$ & $1.766(2)$ & C5-O5 & $1.155(3)$ \\
\hline Fe2-C6 & $1.767(2)$ & C6-O6 & $1.156(3)$ \\
\hline $\mathrm{Fe} 2-\mathrm{C} 7$ & $1.779(2)$ & C7-O7 & $1.160(3)$ \\
\hline $\mathrm{Fe} 2-\mathrm{C} 8$ & $1.781(2)$ & $\mathrm{C} 8-\mathrm{O} 8$ & $1.159(3)$ \\
\hline $\mathrm{Fe} 3-\mathrm{C} 9$ & $1.774(2)$ & C9-O9 & $1.154(3)$ \\
\hline $\mathrm{Fe} 3-\mathrm{C} 10$ & $1.772(3)$ & $\mathrm{C} 10-\mathrm{O} 10$ & $1.151(3)$ \\
\hline Fe3-C11 & $1.776(2)$ & C11-O11 & $1.153(3)$ \\
\hline $\mathrm{Fe} 3-\mathrm{C} 12$ & $1.768(2)$ & $\mathrm{C} 12-\mathrm{O} 12$ & $1.165(3)$ \\
\hline Cd1-N1 & $2.3814(16)$ & $\mathrm{Cd} 1-\mathrm{N} 2$ & $2.4616(17)$ \\
\hline $\mathrm{Cd} 2-\mathrm{N} 3$ & 2.3901(19) & $\mathrm{Cd} 2-\mathrm{N} 4$ & $2.4395(18)$ \\
\hline Cd3-N5 & $2.4967(17)$ & Cd3-N6 & 2.4301(17) \\
\hline \multicolumn{4}{|c|}{ Bond angles } \\
\hline $\mathrm{Fe} 1-\mathrm{Cd} 2-\mathrm{Fe} 3$ & $133.732(10)$ & $\mathrm{C} 1-\mathrm{Fe} 1-\mathrm{C} 2$ & $94.54(11)$ \\
\hline $\mathrm{Fe} 1-\mathrm{Cd} 3-\mathrm{Fe} 2$ & $137.829(10)$ & $\mathrm{C} 1-\mathrm{Fe} 1-\mathrm{C} 3$ & 102.61(11) \\
\hline $\mathrm{Fe} 2-\mathrm{Cd} 1-\mathrm{Fe} 3$ & $138.272(10)$ & C1-Fe1-C4 & $100.21(11)$ \\
\hline $\mathrm{Cd} 1-\mathrm{Fe} 2-\mathrm{Cd} 3$ & $95.439(10)$ & $\mathrm{C} 2-\mathrm{Fe} 1-\mathrm{C} 3$ & $104.13(10)$ \\
\hline $\mathrm{Cd} 1-\mathrm{Fe} 3-\mathrm{Cd} 2$ & $99.481(10)$ & C2-Fel-C4 & $101.90(10)$ \\
\hline $\mathrm{Cd} 2-\mathrm{Fe} 1-\mathrm{Cd} 3$ & $101.855(10)$ & $\mathrm{C} 3-\mathrm{Fe} 1-\mathrm{C} 4$ & $143.59(10)$ \\
\hline Fe1-C1-O1 & $176.1(2)$ & C5-Fe2-C6 & $98.01(10)$ \\
\hline Fel-C2-O2 & $175.9(2)$ & $\mathrm{C} 5-\mathrm{Fe} 2-\mathrm{C} 7$ & 104.93(11) \\
\hline Fel-C3-O3 & $174.7(2)$ & $\mathrm{C} 5-\mathrm{Fe} 2-\mathrm{C} 8$ & $97.20(11)$ \\
\hline Fel-C4-O4 & $172.6(2)$ & $\mathrm{C} 6-\mathrm{Fe} 2-\mathrm{C} 7$ & $95.15(10)$ \\
\hline $\mathrm{Fe} 2-\mathrm{C} 5-\mathrm{O} 5$ & $175.0(2)$ & C6-Fe2-C8 & $97.19(10)$ \\
\hline Fe2-C6-O6 & $177.4(2)$ & $\mathrm{C} 7-\mathrm{Fe} 2-\mathrm{C} 8$ & $152.84(10)$ \\
\hline Fe2-C7-O7 & $170.1(2)$ & $\mathrm{C} 9-\mathrm{Fe} 3-\mathrm{C} 10$ & $95.00(11)$ \\
\hline $\mathrm{Fe} 2-\mathrm{C} 8-\mathrm{O} 8$ & $169.4(2)$ & C9-Fe3-C11 & $101.71(12)$ \\
\hline Fe3-C9-O9 & $175.6(2)$ & $\mathrm{C} 9-\mathrm{Fe} 3-\mathrm{C} 12$ & $102.79(10)$ \\
\hline $\mathrm{Fe} 3-\mathrm{C} 10-\mathrm{O} 10$ & $175.8(2)$ & $\mathrm{C} 10-\mathrm{Fe} 3-\mathrm{C} 11$ & $98.78(13)$ \\
\hline Fe3-C11-O11 & $172.2(2)$ & $\mathrm{C} 10-\mathrm{Fe} 3-\mathrm{C} 12$ & $106.88(11)$ \\
\hline $\mathrm{Fe} 3-\mathrm{C} 12-\mathrm{O} 12$ & $173.8(2)$ & $\mathrm{C} 11-\mathrm{Fe} 3-\mathrm{C} 12$ & $142.47(10)$ \\
\hline N1-Cd1-N2 & $70.10(6)$ & $\mathrm{N} 3-\mathrm{Cd} 2-\mathrm{N} 4$ & $70.51(7)$ \\
\hline N5-Cd3-N6 & $68.54(6)$ & & \\
\hline
\end{tabular}

by the relatively narrow range of Cd-Fe bonds, 2.6969(3)$2.7307(3) \AA$. In addition, there is a much lesser degree of tetrahedral twisting. Only $\mathrm{Fe} 2$ exhibits a notable twist, as evidenced by the $\mathrm{Cd} 1-\mathrm{Fe} 2-\mathrm{C} 6$ and $\mathrm{Cd} 3-\mathrm{Fe} 2-\mathrm{C} 5$ angles of $89.98(7)^{\circ}$ and $76.87(7)^{\circ}$. There are, however, other distortions that are greater for the trimer. The ring is significantly nonplanar, as opposed to the trimeric isomers containing THF, pyridine [10], or bipyridine [11]. Thus, the deviations for $\mathrm{Cd}(1-3)$ and $\mathrm{Fe}(1-3)$ from planarity are $-0.37,-0.02,0.33$, 


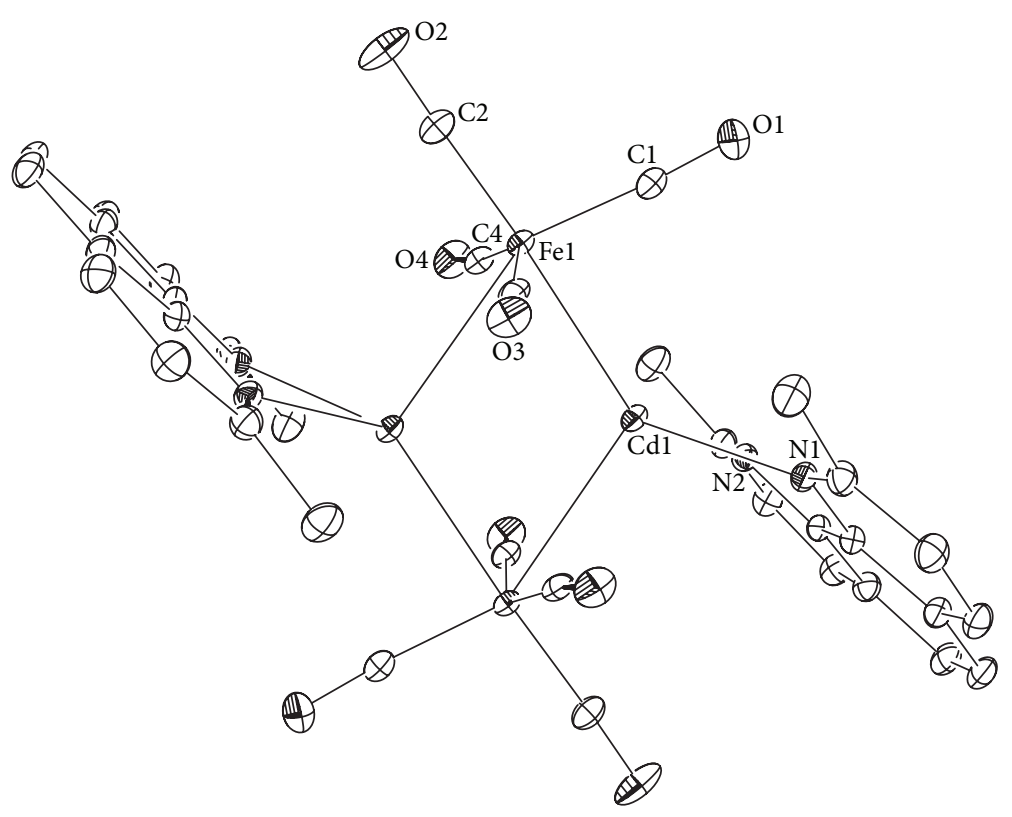

FIGURE 3: Alternative view of $\left[(\text { neocuproine }) \mathrm{CdFe}(\mathrm{CO})_{4}\right]_{2}$ (30\% probability ellipsoids).

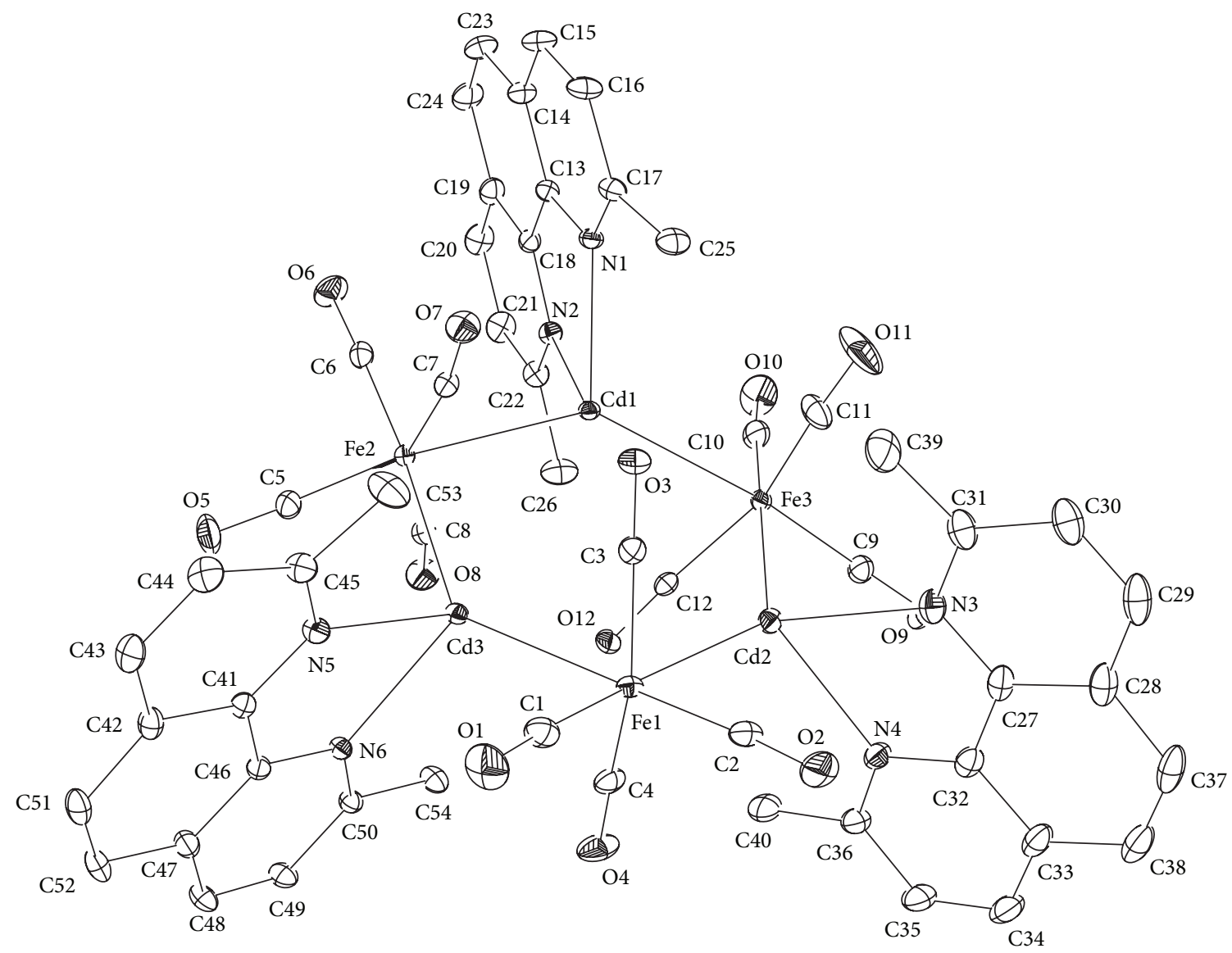

Figure 4: The structure of $\left[(\text { neocuproine }) \mathrm{CdFe}(\mathrm{CO})_{4}\right]_{3}$ (30\% probability ellipsoids). 
$-0.26,0.01$, and $0.31 \AA$ A. Additionally, the axial Fe-C-O angles are slightly smaller, ranging from $169.4(2)^{\circ}$ to $174.7(2)^{\circ}$.

Some additional comparisons may be made with $\left[\left(2,2^{\prime}\right.\right.$ bipyridine $\left.) \mathrm{CdFe}(\mathrm{CO})_{4}\right]_{3}, 5$. The $\mathrm{Cd}-\mathrm{N}$ distances range from $2.3814(16)$ to $2.4967(17) \AA$, as compared to an average value of 2.37(1) $\AA$ for 5, while the $\mathrm{N}-\mathrm{Cd}-\mathrm{N}$ angles range from $68.54(6)$ to $70.51(7)^{\circ}$, versus an average of $68.9(4)^{\circ}$ for 5 . The longer distances may reasonably be attributed to enhanced steric interactions brought about by the methyl substituents on the cuproin ligands. The $\mathrm{Cd}-\mathrm{Fe}-\mathrm{Cd}$ and $\mathrm{Fe}-\mathrm{Cd}-\mathrm{Fe}$ angles range from $95.439(10)^{\circ}$ to $101.855(10)^{\circ}$ and $133.732(10)^{\circ}$ to $138.272(10)^{\circ}$, while the corresponding ranges for 5 were $94.78(14)^{\circ}-102.31(15)^{\circ}$ and $138.61(14)^{\circ}-148.40(15)^{\circ}$.

The trimeric isomer 4 has much less severe $\mathrm{Cd}-\mathrm{Cd}$ contacts as compared to the dimer 3 . The shortest for $\mathbf{4}$ is $4.033 \AA(\mathrm{Cd} 1 / \mathrm{Cd} 3)$, nearly $1 \AA$ longer than the $3.085 \AA$ in 3 . On the other hand, 3 has two interactions between carbonyl oxygen atoms (O3/O7, $2.975 \AA$; O8/O12, 2.939 $\AA$ ) that are significantly shorter than those in the dimer (vide supra). Furthermore, while 3 has carbonyl oxygen/methyl contacts of 3.190 and $3.148 \AA, 4$ has not only such contacts but also shorter ones of 3.028 (O7/C25), 3.031 (O4/C54), and 3.122 (O8/C26) A. One also observes a marked asymmetry in the $\mathrm{Cd}-\mathrm{N}$ bonds for the trimer (Table 3 ) but not for the dimer.

\section{Conclusions}

Through variation of the crystallization method, it has been found possible to isolate both dimeric and trimeric forms of (neocuproine) $\mathrm{CdFe}(\mathrm{CO})_{4}$. Trimeric cadmium iron complexes already had a precedent in other complexes with THF and amine ligands, while the dimeric structure had not previously been observed. Due to the methyl groups on the neocuproine ligands, these species exhibited substantially greater distortions as compared to the related $\left[\left(2,2^{\prime}\right.\right.$ bipyridine $\left.) \mathrm{ZnFe}(\mathrm{CO})_{4}\right]_{2}$ and $\left[\left(2,2^{\prime} \text {-bipyridine }\right) \mathrm{CdFe}(\mathrm{CO})_{4}\right]_{3}$ complexes.

\section{Conflict of Interests}

The authors declare that there is no conflict of interests regarding the publication of this paper.

\section{References}

[1] F. Feigl and P. Krumholz, "Über Salze des Eisencarbonylwasserstoffs," Zeitschrift für Anorganische und Allgemeine Chemie, vol. 215, pp. 242-248, 1933.

[2] A. T. T. Hsieh, M. J. Mays, and R. H. Platt, "Infrared and Mössbauer spectra of tetracarbonylcadmioiron and related complexes," Journal of the Chemical Society A, pp. 3296-3300, 1971.

[3] R. D. Ernst, T. J. Marks, and J. A. Ibers, "Metal-metal bond cleavage reactions. The crystallization and solid state structural characterization of cadmium tetracarbonyliron, $\mathrm{CdFe}(\mathrm{CO}) 4$," Journal of the American Chemical Society, vol. 99, no. 7, pp. 2090-2098, 1977.

[4] H. Hock and H. Stuhlmann, "Über die Einwirkung von Quecksilbersalzen auf Eisenpentacarbonyl (II. Mitteil.), Berichte der
Deutschen Chemischen Gesellschaft, vol. 62, no. 2, pp. 431-437, 1929.

[5] R. D. Ernst and T. J. Marks, "Chemical and structural relationships among the oligomeric compounds $\mathrm{MFe}(\mathrm{CO})_{4}(\mathrm{M}=$ $\mathrm{Zn}, \mathrm{Cd}, \mathrm{Hg}), \mathrm{PbFe}(\mathrm{CO})_{4}, \mathrm{AgCo}(\mathrm{CO})_{4}$, and their base adducts," Inorganic Chemistry, vol. 17, no. 6, pp. 1477-1484, 1978.

[6] B. E. Zaugg, T. Kolb, A. M. Arif, and R. D. Ernst, "Structural studies of (pyridine) ${ }_{3} \mathrm{ZnFe}(\mathrm{CO})_{4}$ and (pyridine) (neocuproin) $\mathrm{CdFe}(\mathrm{CO})_{4}$," Journal of Chemical Crystallography, vol. 40, no. 9, pp. 778-782, 2010.

[7] O. Fuhr and D. Fenske, "Syntheses and structure elucidations of novel (ironcarbonyl)zinc and -cadmium chloride derivatives," Zeitschrift für Anorganische und Allgemeine Chemie, vol. 626, no. 8, pp. 1822-1830, 2000.

[8] V. G. Albano, M. Monari, F. Demartin et al., "Synthesis and chemical behavior of $\left[\mathrm{MFe}_{4}(\mathrm{CO})_{16}\right]^{\mathrm{n}-}(\mathrm{M}=\mathrm{Au}, \mathrm{Zn}, \mathrm{Cd}, \mathrm{Hg})$ clusters: $\mathrm{X}$ ray structure of $\left[\mathrm{NMe}_{3} \mathrm{CH}_{2} \mathrm{Ph}\right]_{2}\left[\mathrm{Au}\left\{\mathrm{Fe}_{2}(\mathrm{CO})_{8}\right\} 2\right] \mathrm{Cl}$ and $\left[\mathrm{PPh}_{4}\right]_{2}\left[\mathrm{Cd}\left\{\mathrm{Fe}_{2}(\mathrm{CO})_{6}(\mu-\mathrm{CO})_{2}\right\}_{2}\right] 2 \mathrm{CH}_{3} \mathrm{CN}$," Solid State Sciences, vol. 1, no. 7-8, pp. 597-606, 1999.

[9] W. Deck, A. K. Powell, and H. Vahrenkamp, "Cluster mit Fe ${ }_{6} \mathrm{Cd}-$ und $\mathrm{Fe}_{6} \mathrm{Hg}$-Baueinheiten," Journal of Organometallic Chemistry, vol. 428, no. 3, pp. 353-362, 1992.

[10] R. D. Ernst, T. J. Marks, and J. A. Ibers, "Metal-metal bond cleavage reactions. The crystal and molecular structure of $\left(2,2^{\prime}\right.$-bipyridyl)cadmium tetracarbonyliron, (bpy) $\mathrm{CdFe}(\mathrm{CO})_{4}$, , Journal of the American Chemical Society, vol. 99, no. 7, pp. 2098-2107, 1977.

[11] R. J. Neustadt, T. H. Cymbaluk, R. D. Ernst, and F. W. Cagle Jr., "Crystallization and solid-state structural characterization of (2,2' -bipyridyl)zinc tetracarbonyliron, (bpy) $\mathrm{ZnFe}(\mathrm{CO})_{4}$," Inorganic Chemistry, vol. 19, no. 8, pp. 2375-2381, 1980.

[12] Z. Otwinowski and W. Minor, "Processing of X-ray diffraction data collected in oscillation mode," Methods in Enzymology, vol. 276, pp. 307-326, 1997.

[13] A. Altomare, M. C. Burla, M. Camalli et al., "SIR97: a new tool for crystal structure determination and refinement," Journal of Applied Crystallography, vol. 32, no. 1, pp. 115-119, 1999.

[14] G. M. Sheldrick, "A short history of SHELX," Acta Crystallographica A, vol. 64, no. 1, pp. 112-122, 2008.

[15] D. C. Creagh and W. J. McDauley, in International Tables for Crystallography: Mathematical, Physical and Chemical Tables, A. J. C. Wilson, Ed., chapter 4, pp. 206-222, Kluwer Academic Publishers, Dordrecht, The Netherlands, 1992.

[16] E. N. Maslen, A. G. Fox, and M. A. O'Keefe, in International Tables for Crystallography: Mathematical, Physical and Chemical Tables, A. J. C. Wilson, Ed., chapter 6, pp. 476-516, Kluwer Academic Publishers, Dordrecht, The Netherlands, 1992.

[17] L. J. Farrugia, "ORTEP-3 for windows-a version of ORTEPIII with a graphical user interface (GUI)," Journal of Applied Crystallography, vol. 30, no. 5, p. 565, 1997. 

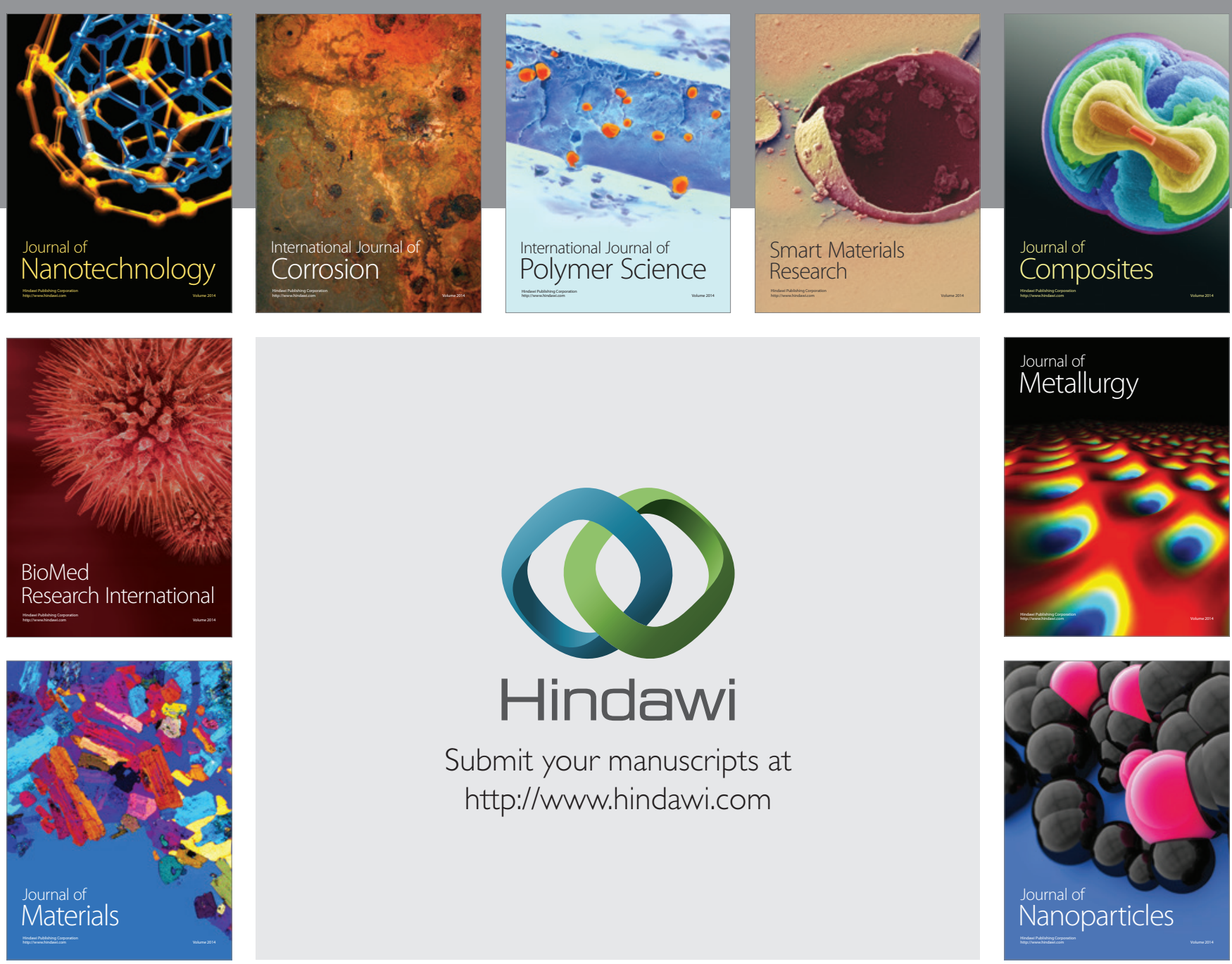

Submit your manuscripts at http://www.hindawi.com
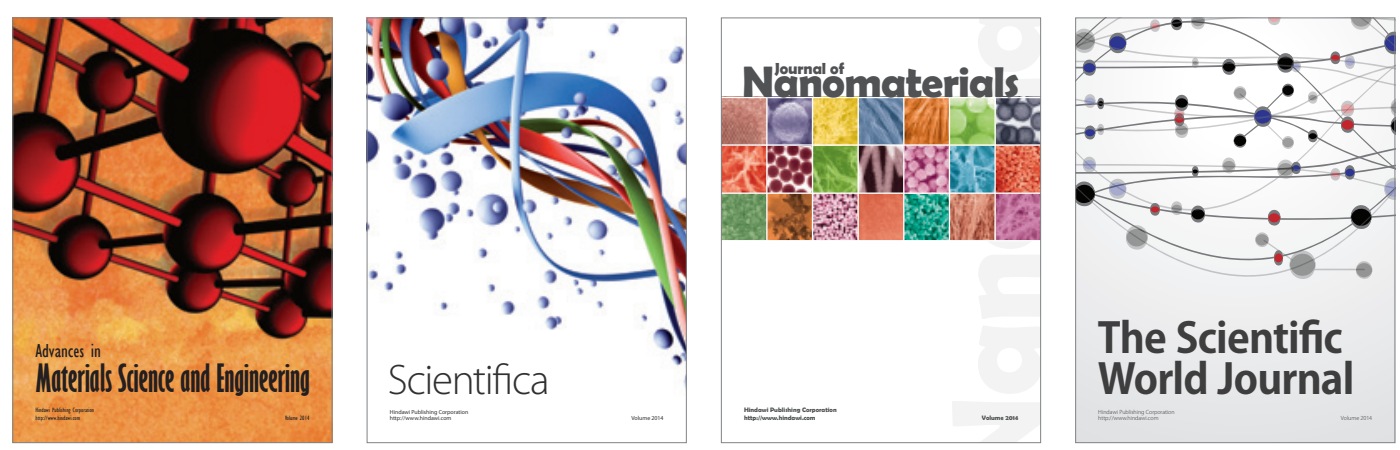

\section{The Scientific World Journal}
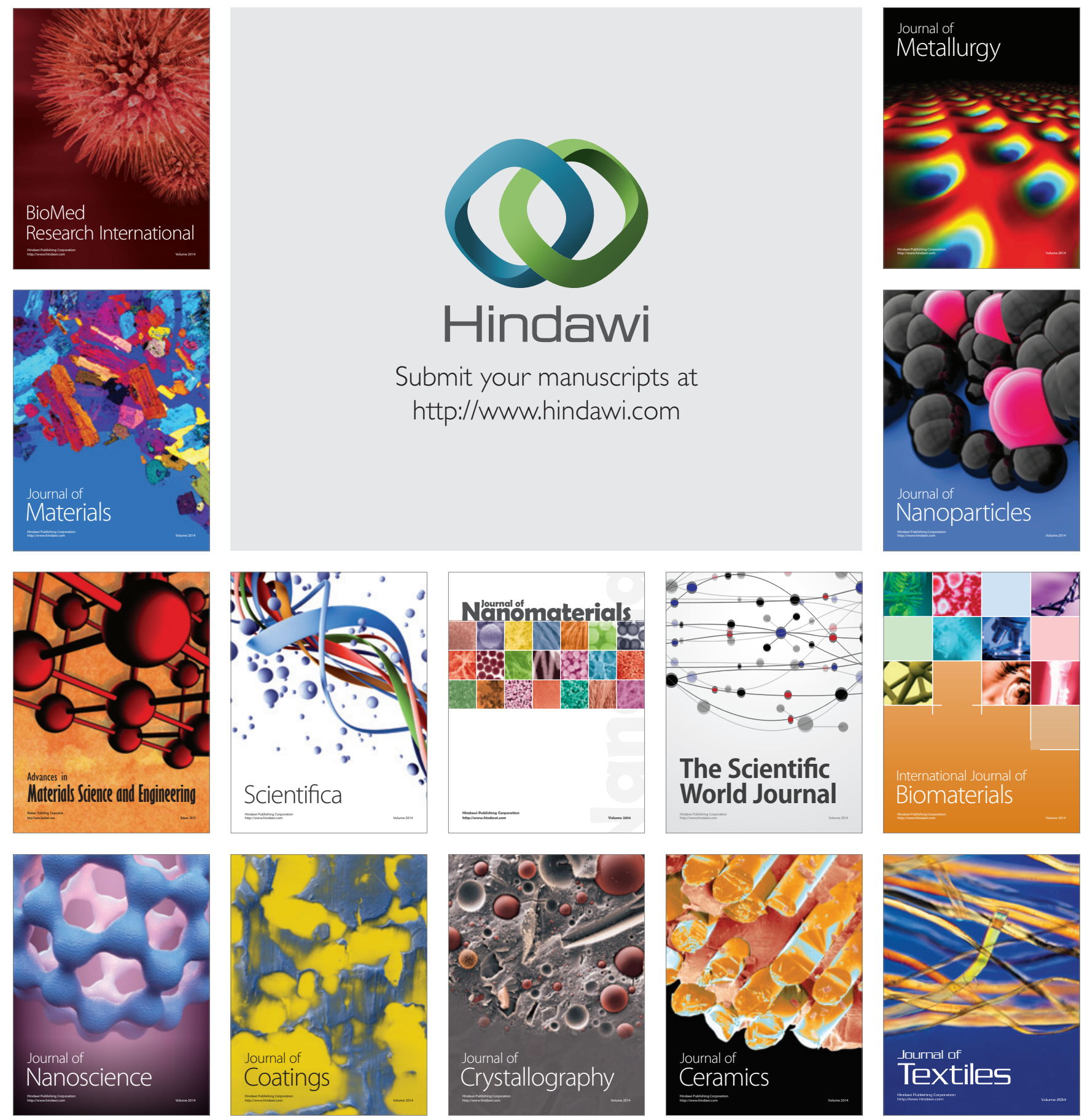